\title{
Impact of Flooding on Fishermen's families in Pedro Community, Iwaya-Lagos, Nigeria
}

\section{$*^{1}$ CHUKWU, MN}

\author{
School of Science and Technology, \\ National Open University of Nigeria, Lagos, Nigeria \\ mchukwu@noun.edu.ng, Phone: +2348033079536
}

KEY WORDS: climatic change, flooding, fishermen, fishing implements.

\begin{abstract}
Climatic change impact is envisaged to lead to increase in the frequency of occurrence of floods. This study examined the effect of flooding on fishermen's families in Pedro village, Iwaya, Lagos. A total of 50 fishermen living in Pedro Community, Iwaya-Lagos, Nigeria were interviewed using structured questionnaires that were distributed through a simple random sampling technique. Data collected were summarized and computed using descriptive statistics. Results showed that flooding was a dominant seasonal climatic factor. Seventy-six percent of the respondents stated that flooding distorted the fishing business, destroyed fishing implements and impacted negatively on their social life. Flooding also interrupted children's schooling, increased environmental pollution, reduced fish catch and consequently family income and also increased the occurrence of water borne diseases. Most $(96 \%)$ of the respondents would not like their children to continue with fishing and will opt out if they get alternative means of livelihood. The study recommended that efforts to remedy the adverse effects of flooding should include provision of alternative skill development and affordable health services for treatment of water born diseases. () JASEM
\end{abstract}

http://dx.doi.org/10.4314/jasem.v18i4.13

\section{Introduction}

Nigeria had experienced many setbacks that resulted from environmental hazards, some being natural and others man-made. Natural hazards include storm, erosion, drought, diseases and flooding. On the category of man-made hazards are conflicts, oil spills and accidents. Flooding is a natural disaster that frequently impact negatively on the inhabitants of the coastal region of Nigeria. Climatic change impacts are believed to increase frequency of occurrence of floods (Ayo-Lawal, 2007, Osman-Elasha, SpangerSiegfried, Goutbi, and Hanafi, 2007). It was estimated that with a $70 \mathrm{~cm}$ sea level rise, the number of people at risk of annual flooding could increase from 46 million to 90 million (Jepma, and Munasinghe, 1998).

There is thus need for urgent intervention through emergency preparedness mechanisms and involvement of the government and other relevant stakeholders (Intergovernmental Panel on Climate Change (IPCC), 2001, Nhemachena, and Hassan, (2007).

Many families in coastal areas are vulnerable to the impact of climate change because of their low adaptive capacity to climate change (Gwary, 2008). Environmental problems caused by flooding include damages to infrastructure, destruction of aquaculture, livestock and crop farms. Ayo-Lawal, (2007) reported a loss of 560 farmlands in Taraba state where despite some preventive mechanisms that were in place, livelihoods were lost.

The consequences of flood due to climate change include reduction in fish catch, erosion of human habitat and reduction of income of fishermen. Flood also affects health resulting in outbreak of diseases like cholera, dysentery, malaria and yellow fever and increases the chances of famine in areas with inadequate coping systems (Blaikie, 1994). Contamination of water during flooding may lead to outbreaks of water-borne diseases such as typhoid, cryptosporidium and cholera.

The various impacts of flooding have led the fishermen to adopt different coping mechanisms such as moving to other place of abode, temporary relocation, moving to other fishing sites, regular dredging of rivers and improved control of river siltation. Many fishing communities in Lagos live in riverine areas thus the fishermen should be educated on the signs to watch out for and preventive measures to take in event of flooding. The government had taken some combating measures such as digging of boreholes, wells and afforestation of sand dunes 
delineation of flood and erosion hazard areas. Presently, sea level observation is being carried out by NIOMR UNESCO/CSI (2000) and embankments are in place in Lagos Marina using sheet pilings and moles. This paper assessed the impact of flooding on fishermen families dwelling in Pedro community.

Objective: The objective of this study is to investigate the effect of flooding on the fisher folks families in Petro community, Lagos with a view of finding the best option to mitigate the effect.

In other to find this objective, the following research questions were asked

i. How does flooding affect the fishermen's families in Pedro community? ii. What measures can be taken to mitigate the effect of the flooding?

Materials and Methods

Study Area: Pedro community is a riverine area in Lagos state; located in the lagoon region of the southwestern Nigeria. The village was selected for studying because it is covered by water bodies; as a result the inhabitants are engaged in fishing. This occupation was inherited from their parents

A sample of 50 fishermen was randomly selected from a population of 533 fishermen and interviewed. Data were collected through observations and personal interviews using structured questionnaire. Section A of the questionnaire focused on the socioeconomic characteristics of the respondents while Section B had 18 Likert type items and was designed to assess the impact of flooding on fishermen. The questionnaire was validated in order to improve the quality and content before administration. The testreset reliability scale yielded reliability coefficient of 0.78 .
Data collected were summarized and computed using descriptive statistics (frequency and percentages), while information on the influence of flooding on various activities of the Fishermen's families were computed on a four point Likert Rating Scale (LRS), as strongly agreed $=4$, agreed $=3$, disagreed $=2$, strongly disagreed $=1$. The mean score was computed as $4+3+2+1=10 / 4=2.50$. Using the interval score of 0.05 , the upper limit cut-off was determined as $2.50 \pm$ 0.05 and the lower limit as $2.55 \pm 0.05=2.45$. On the basis of this, mean score (MS) below 2.45 (i.e. <2.45) were ranked 'low', those between 2.45 and 2.54 were considered 'medium' (i.e. $2.45 \geq \mathrm{MS} \leq 2.54$ ), while the mean score greater than or equal to 2.55 (i.e. MS $\geq 2.55$ ) were considered 'high'.

\section{RESULTS AND DISCUSSION}

Socio-Economic Characteristics of the Respondents: The summary of selected socio-economic characteristics of fishermen in Pedro community is shown in Table 1. The average age of the fishermen is 40 years; the youngest and the oldest being 25 and 64 years old respectively. The majority (78\%) of the fishermen were below 50 years old. This is an indication that the fishing community is still young and energetic with the potential to develop and run the fishery sustainably. Most of the fishermen (76\%) are married with only $24 \%$ singles. The children and spouses of the fishermen can serve as a potential source of labor for the fishery. The average family size for most $(70 \%)$ of the fishermen ranged between 4 and 9 children, most of which are potential source of labor availability for fishing activities. Only 38\% had attained secondary education while the rest $(76 \%)$ had at least attended primary school. This implies that if a new innovation is introduced, the fishermen will not be challenged in understanding it. Such an innovation can focus on improving the catches. The average fishing experience for the fishermen was about 8 years. Most $(72 \%)$ of the fishermen belonged to where they received assistance in form of cash and kind during disasters.

Table1: Socio-economic characteristics of the fishermen

\begin{tabular}{|c|c|c|c|}
\hline Characteristics & & Frequency & $\begin{array}{c}\text { Percentage } \\
(\%)\end{array}$ \\
\hline Age & $\begin{array}{l}21-30 \text { years } \\
31-40 \text { years } \\
41-50 \text { years } \\
51 \text { years and above } \\
\text { Average } 40 \text { years }\end{array}$ & $\begin{array}{l}08 \\
17 \\
14 \\
11\end{array}$ & $\begin{array}{l}16 \\
34 \\
28 \\
22\end{array}$ \\
\hline Marital status & $\begin{array}{l}\text { Single } \\
\text { Married }\end{array}$ & $\begin{array}{l}12 \\
38\end{array}$ & $\begin{array}{l}24 \\
76\end{array}$ \\
\hline Family size & $\begin{array}{l}1-3 \\
4-6 \\
7 \text { and above }\end{array}$ & $\begin{array}{l}15 \\
22 \\
13\end{array}$ & $\begin{array}{l}30 \\
44 \\
26\end{array}$ \\
\hline Educational attainment & $\begin{array}{l}\text { No formal Education } \\
\text { Primary } \\
\text { Secondary } \\
\text { Tertiary }\end{array}$ & $\begin{array}{l}12 \\
15 \\
19 \\
04\end{array}$ & $\begin{array}{l}24 \\
30 \\
38 \\
08 \\
\end{array}$ \\
\hline Membership of Associations & $\begin{array}{l}\text { Yes } \\
\text { No }\end{array}$ & $\begin{array}{l}36 \\
14\end{array}$ & $\begin{array}{l}72 \\
28\end{array}$ \\
\hline
\end{tabular}


Impact of Flooding on Fishermen's families in Pedro Community

Impact of Flooding to Fishermen's Livelihoods

Table 2: Extent of loss experienced by fishermen due to flooding (July - October, 2013)

\begin{tabular}{llcc}
\hline Variable & Frequency & $\begin{array}{l}\text { Percentage } \\
(\%)\end{array}$ \\
\hline Flooding Experience & $\begin{array}{l}\text { Experience loss } \\
\text { Did not experience } \\
\text { loss }\end{array}$ & 38 & 76 \\
& $80 \%$ & 12 & 24 \\
\hline Proportion of loss & $60 \%$ & 05 & 10 \\
experienced & $40 \%$ & 09 & 18 \\
& $20 \%$ & 14 & 28 \\
& 22 & 44 \\
\hline
\end{tabular}

Majority (76\%) of the fishermen encountered loss due to .flooding. The loss included destruction of the fishing implements, disruption of the children's schooling, higher risks to environmental pollution, and reduction in fish catches and consequently family income. Other than destroying property, flooding causes high incidences of malaria infection and infection to water borne diseases.

Flooding occurs during the peak of the rainy season between the months of July and October. This results in decline of fish catches which tend to be higher during the dry season when the volume of water is low.
Respondents' coping mechanisms against flooding: The coping mechanisms adopted by the fishermen to solve the problem of flooding are shown in Figure 4. If fishermen could be forewarned of potential floods then they could take appropriate precautionary measures. The government has not provided any support during the past period of flooding. Fishermen have devised various coping mechanisms at home and at the fishing site. Sixty-four percent of the fishermen had relocated. Only $16 \%$ temporarily relocated and then returned to the fishing village afterwards. In the same manner, $28 \%$ of the fishermen moved to another fishing site. Most of the respondents would not like their children to continue with fishing and will opt out if they get alternative means of livelihood.

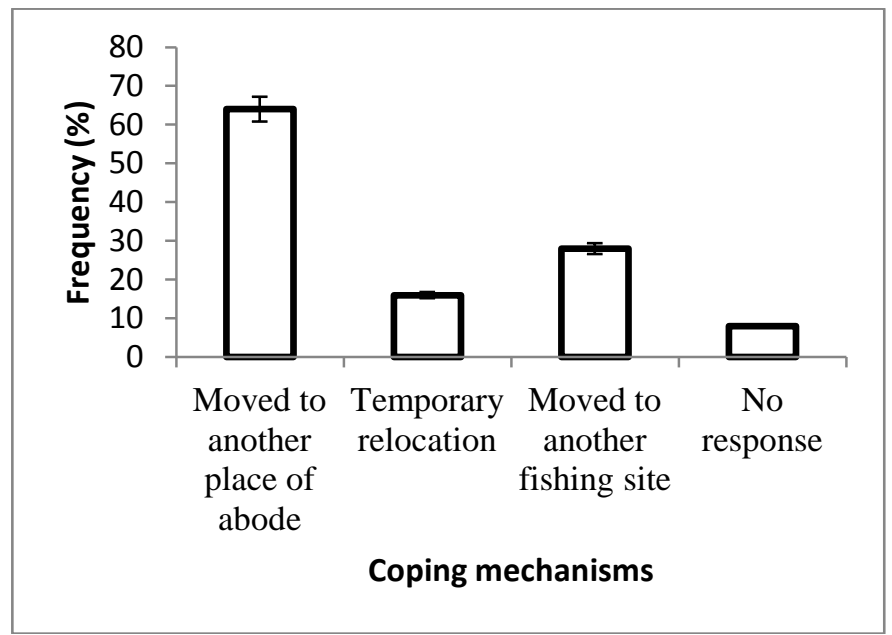

Fig 4: Respondents' coping mechanisms against flooding.

Influence of Flooding on the Various Activities of the Fishermen's Families:

Table 3 shows the impact of flooding on the various activities of the fishermen's families. Mean scores greater 2.55 were rated as high. Based on this, flooding was found to have a significant effect on the sea's water volume, quantity and quality of fish caught, family business and income. It also had significant influence on the fishermen's implement, business, children's schooling and their environment as a whole. The fishermen's families are indeed suffering seriously as a result of the pronounced negative effects of the flooding. The government and 
other stakeholders should devise appropriate ways to fishermen's lives. mitigate the negative impact of flooding on the

Table 3: The impact of flooding on the various activities of the fishermen's families

\begin{tabular}{|c|c|c|c|c|c|c|}
\hline Variables & $\begin{array}{l}\text { Strongly } \\
\text { disagreed }\end{array}$ & Disagreed & Agreed & $\begin{array}{l}\text { Strongly } \\
\text { agreed }\end{array}$ & Total & $\begin{array}{l}\text { Mean } \\
\text { Score }\end{array}$ \\
\hline $\begin{array}{l}\text { Influence of flooding on water } \\
\text { volume. }\end{array}$ & $0(0.00)$ & $0(0.00)$ & $21(1.26)$ & $29(1.74)$ & 50 & 3.00 \\
\hline $\begin{array}{l}\text { Influence of flooding on number of } \\
\text { fish caught }\end{array}$ & $0(0.00)$ & $0(0.00)$ & $21(1.26)$ & $29(1.74)$ & 50 & 3.00 \\
\hline Seasonal influence of flooding. & $0(0.00)$ & $0(0.00)$ & $25(1.50)$ & $25(2.00)$ & 50 & 3.50 \\
\hline $\begin{array}{l}\text { Influence of flooding on individual } \\
\text { families. }\end{array}$ & $0(0.00)$ & $0(0.00)$ & $29(1.16)$ & $21(1.68)$ & 50 & 2.84 \\
\hline Fishing as family's business. & $0(0.00)$ & $0(0.00)$ & $7(0.42)$ & $43(3.44)$ & 50 & 3.86 \\
\hline $\begin{array}{l}\text { Influence of flooding on children's } \\
\text { occupation. }\end{array}$ & $33(0.66)$ & $17(0.68)$ & $0(0.00)$ & $0(0.00)$ & 50 & 1.34 \\
\hline $\begin{array}{l}\text { Influence of flooding on family's } \\
\text { income. }\end{array}$ & $0(0.00)$ & $0(0.00)$ & $21(1.26)$ & $29(1.74)$ & 50 & 3.00 \\
\hline Health implications of flooding. & $0(0.00)$ & $31(1.24)$ & $19(1.14$ & $0(0.00)$ & 50 & 1.38 \\
\hline Rates of flooding. & $0(0.00)$ & $4(0.16)$ & $45(2.70)$ & $1(0.08)$ & 50 & 2.94 \\
\hline $\begin{array}{l}\text { Influence of flooding on fishermen's } \\
\text { abode. }\end{array}$ & $0(0.00)$ & $5(0.20)$ & $45(2.70)$ & $0(0.00)$ & 50 & 2.90 \\
\hline Influence of flooding on vegetations. & $5(0.10)$ & $39(1.56)$ & $1(0.06)$ & $5(0.40)$ & 50 & 2.12 \\
\hline Psychological influence of flooding. & $43(0.86)$ & $6(0.24)$ & $1(0.06)$ & $0(0.00)$ & 50 & 1.16 \\
\hline $\begin{array}{l}\text { Influence of flooding on fishing } \\
\text { implements. }\end{array}$ & $0(0.00)$ & $7(0.28)$ & $12(0.72)$ & $31(2.48)$ & 50 & 3.48 \\
\hline Interactive influence of flooding. & $22(0.44)$ & $28(1.12)$ & $0(0.00)$ & $0(0.00)$ & 50 & 1.56 \\
\hline $\begin{array}{l}\text { Influence of flooding on children's } \\
\text { schooling. }\end{array}$ & $0(0.00)$ & $1(0.04)$ & $42(0.52)$ & $7(0.56)$ & 50 & 3.12 \\
\hline $\begin{array}{l}\text { Influence of flooding on the } \\
\text { environment. }\end{array}$ & $0(0.00)$ & $0(0.00)$ & $24(1.44)$ & $26(2.08)$ & 50 & 3.52 \\
\hline
\end{tabular}

The research findings showed that the majority fishermen are still young consequently it can be deduced that they have the potential to develop and sustainably run the fishery. However flooding is currently a major threat to the fishermen's livelihoods especially the resultant decline in fish catches which then threaten family income and the prevalence of water borne diseases.

Recommendations: Based on the findings of the study, the following recommendations are made:

The fishermen in the community need financial assistance from the government to enhance large scale operation.

There is a need to educate the fishermen on possible climate change to forestall flooding disasters.

The non-governmental organizations should educate the fishermen on the coping and control mechanisms to use to combat the adverse effects of flooding.

The government and non-governmental organizations should provide the members of the community with affordable health services for treatment of water borne diseases.

There is also the need for provision of an alternative skill development programme for the inhabitants.

Acknowledgement: I wish to appreciate the community and their leaders for their understanding and cooperation throughout the period of the study. I also appreciate. Mr. Alex Chukwu for his moral and financial support.

\section{REFERENCES}

Ayo-Lawal, G. (2007). Showers of Agony, Ruin and Death Nigerian Tribune Wed 28th November 2007. From http://www.tribune.com.ng

Blaikie, P. (1994). At Risk: Natural Hazards, People's Vulnerability, and Disasters. London: Routledge.

Gwary, D. (2008). Climate change, Food security and Nigeria Agriculture. Workshop on the 
Impact of Flooding on Fishermen's families in Pedro Community

challenges of climate change for Nigeria. NISER. 19th $-20^{\text {th }}$ May, 2008.

Intergovernmental Panel on Climate Change (IPCC) (2001). 'Climate Change 2001: Synthesis Report', Contribution of Working Groups I, II and III to the Third Assessment Report of the Intergovernmental Panel on Climate Change. Edited by RT Watson and Core Team. Cambridge: Cambridge University Press. JackyPutt NJ 2007. Coastal Population and Shoreline Degradation: A Case Study of LagosIbeju/Lekki Corridor. Unpublished Thesis. Department of Urban and Regional Planning, University of Ibadan, Nigeria.

Jepma, C. and Munasinghe M. (1998). Climate Change Policy:Facts, Issues and Analyses Cambridge: Cambridge University Press.

Nhemachena, C., Hassan, R. (2007). Micro-level analysis of farmers' adaptation to climate hange in Southern Africa. IFPRI Discussion Paper No. 00714. International Food
Policy Research Institute, Washington, DC. Osman-Elasha, B. E., Spanger-Siegfried, N., Goutbi, S. Z. and Hanafi, A. (2007). Sustainable livelihood measures: Lessons for climate change adaptation in arid regions of Africa. Annals of Arid Zone 4 4(3 and 4): 403419

Okeke, I. C. (2003). Coastal challenges and the challenges of coastal education in Nigeria. Paper presented to Conek International, Lagos.

Osman-Elasha, B. E., Spanger-Siegfried, N., Goutbi, S. Z. and Hanafi, A. (2007). Sustainable livelihood measures: Lessons for climate change adaptation in arid regions of Africa. Annals of Arid Zone 4 4(3 and 4): 403-419.

UNESCO/CSI (2000). Study of Main Drainage Channels of Victoria and Ikoyi Islands in Lagos Nigeria and their Response to Tidal and Sea Level Changes. From <http://www.unesco.org/csi>. 